\title{
KAMPUNG LEUSER: TANTANGAN DAN PROSPEK SEBUAH PERMUKIMAN INFORMAL DI KEBAYORAN BARU
}

\author{
Roberto $^{1}$, Erwin Fahmi ${ }^{2}$ \\ ${ }^{12}$ Program Studi Magister Perencanaan Wilayah dan Kota, Universitas Tarumanagara \\ Email: robeerto1208@gmail.com
}

Masuk: 30-03-2020, revisi: 27-29-2021, diterima untuk diterbitkan: 06-10-2021

\begin{abstract}
ABSTRAK
Kebayoran Baru merupakan kota baru yang direncanakan dengan baik. Namun, seiring berjalannya waktu, Kebayoran Baru mengalami transformasi, baik direncanakan maupun tidak. Salah satu bentuk transformasi di Kebayoran Baru adalah hadirnya permukiman informal, seperti yang antara lain berada di Jalan Leuser. Kampung yang diklaim oleh warga telah dihuni sejak 1955 ini, dalam perjalanannya mengalami berbagai tantangan, salah satunya adalah ancaman pengambil-alihan lahan dan penggusuran. Ancaman penggusuran ini bermula dari sengketa tanah yang melibatkan pihak warga Kampung Leuser selaku pihak yang menempati lahan dan PAM Jaya selaku pihak yang mengklaim memiliki hak atas lahan tersebut. Berbekal sertifikat HGB atas namanya, pihak PAM Jaya pada 2016 meminta warga untuk segera meninggalkan lahan tersebut. Warga yang mengaku sudah tinggal di lahan tersebut sejak lebih dari 60 tahun dengan tegas menolak klaim pihak PAM Jaya dan melakukan perlawanan. Penelitian ini menggunakan pendekatan penelitian kualitatif dan perspeltif semi autonomous social field, bertujuan untuk memahami tantangan penguasaan efektif warga atas tanah tersebut, dan prospek permukimannya ke depan. Tantangan dirumuskan melalui latar belakang penguasaan warga atas lahan tersebut, proses, dan perkembangannya hingga saat ini. Sementara, prospek disajikan melalui skenario jalan keluar yang dapat ditempuh, baik skenario pesimis, moderat, maupun optimis. Hasil penelitian menunjukkan bahwa hingga saat ini (2019), empat tahun setelah rencana penggusuran bermula, Kampung Leuser masih bertahan. Bahkan, pihak warga juga sudah menggugat BPN selaku pihak yang mengeluarkan sertifikat HGB untuk PAM Jaya. Hal ini membuktikan bahwa bertahannya eksistensi Kampung Leuser bukanlah hal yang tidak mungkin. Dari tiga skenario yang dapat ditempuh ke depan, maka skenario moderat dapat memberikan rasa keadilan bagi berbagai pihak. Lebih jauh diharapkan sengketa ini dapat menjadi pembelajaran bagi bidang ilmu perencanaan wilayah dan kota baik secara praktis maupun teoritis mengenai solusi dalam pengelolaan permukiman informal, baik di kota baru Kebayoran Baru, maupun di kota-kota baru lainnya di Indonesia.
\end{abstract}

Kata kunci: permukiman informal; semi-autonomous social field; Kampung Leuser - Kebayoran Baru

\section{ABSTRACT}

Kebayoran Baru was a well-planned new town. However, over time, Kebayoran Baru has been transforming, whether it is planned or not. One form of transformation in Kebayoran Baru has been the presence of informal settlements, such as those on Jalan Leuser. The kampong, which is claimed by its residents has been inhabited since 1955, has faced various challenges along the way, one of which is the threat of land expropriation and eviction. The threat of eviction stems from a land dispute involving the residents of Kampung Leuser as the party occupying the land and PAM Jaya as the party who claims to have rights to the land. Equiped with an HGB certificate under its name, PAM Jaya in 2016 requested residents to leave the land immediately. Residents who claimed to have lived on the land for more than 60 years firmly rejected PAM Jaya's claim and fought back. This study uses a qualitative research approach and a semi-autonomous social field perspective, aiming to understand the challenges of effective citizen control over the land and the prospects for future settlements. The challenges are formulated based on the background of the people's control over the land, the process, and its development until now. Meanwhile, prospects are presented through possible scenarios, either pessimistic, moderate, or optimistic scenarios. The results show that until now (2019), four years after the eviction plan began, Kampung Leuser still survives. In fact, the residents have also sued BPN as the party that issued the HGB certificate for PAM Jaya. This proves that the survival of Kampung Leuser is not impossible. Of the three scenarios that can be pursued in the future, the moderate scenario can provide a sense of justice for various parties. Furthermore, this dispute is expected to provide a lesson for the field of regional and urban planning, both practically and theoretically, regarding solutions in the management of informal settlements, both in the new city of Kebayoran Baru, as well as in other new cities in Indonesia. 


\section{PENDAHULUAN \\ Latar Belakang}

Kebayoran Baru saat ini adalah sebuah kecamatan di kota Jakarta Selatan. Pada awalnya, Kebayoran Baru merupakan sebuah kota baru yang dirancang untuk menjadi penyangga bagi Kota Jakarta dan secara administratif terpisah dari gemeente Batavia. Namun, dalam perjalanannya Kebayoran Baru mengalami perubahan atau transformasi. Ada dua pola perubahan yang terjadi di Kebayoran Baru. Pertama, adalah perubahan yang terencana. Salah satu contohnya adalah perubahan yang terjadi pada kawasan greenbelt timur Kebayoran Baru ${ }^{1}$. Pada mulanya kawasan ini dimaksudkan sebagai kawasan penyangga yang membatasi bagian timur Kebayoran Baru dengan kawasan di luarnya. Namun, sejalan dengan waktu, termasuk dengan adanya Instruksi Gubernur No. 302 Tahun 1997, sebagian dari kawasan tersebut berubah menjadi kawasan pemerintahan/Kantor Walikota Jakarta Selatan. Kedua, adalah perubahan tidak terencana, berupa munculnya permukiman informal di Kebayoran Baru. Salah satu contohnya adalah kawasan permukiman informal di Jalan Ophir dan Jalan Leuser, Kelurahan Gunung, Kebayoran Baru. Pada mulanya, kedua kawasan ini merupakan jalur hijau berupa tanah kosong dan rawa, namun seiring berjalannya waktu jalur hijau ini berubah menjadi permukiman informal.

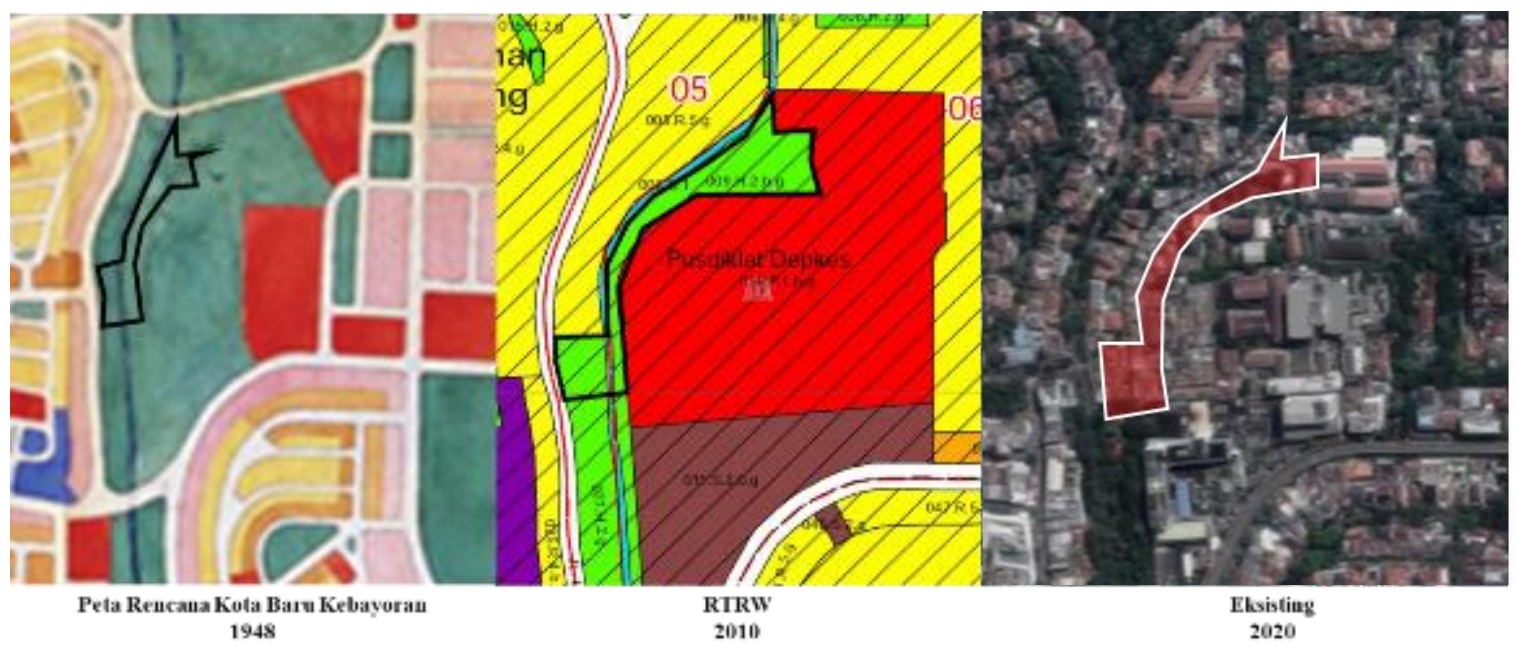

Gambar 1. Perbandingan Peta Lokasi berdasarkan Rencana Kota Baru Kebayoran 1948, RTRW 2010, dan keadaan eksisting 2020

Sumber: Olahan Penulis

Salah satu kawasan permukiman informal dimaksud adalah Kampung Leuser yang berada di Jalan Leuser, RT005, 006, 007, 008, 010, RW08, Kelurahan Gunung, Kecamatan Kebayoran Baru. Kawasan ini memiliki luas 10.500m2. Berdasarkan Peta Rencana Kota Baru Kebayoran tahun 1948 dan Peta RTRW 2010, terdapat perbedaan antara peruntukan kawasan tersebut dan keadaannya saat ini. Kawasan yang menurut rencana kota merupakan jalur hijau, saat ini berubah menjadi kawasan permukiman padat. Perubahan ini mencuatkan, pada tahun 2016, kasus sengketa atas lahan tersebut antara warga yang menghuni Kampung Leuser tersebut dan PAM Jaya, yang dapat berakibat penggusuran bagi warga.

\footnotetext{
${ }^{1}$ Tentang transformasi kawasan sabuk hijau Timur ini, lihat Claudio, Glen dan Erwin Fahmi. 2020. "Rencana Sabuk Hijau Timur Kota Baru Kebayoran: Kebijakan Setengah Hati? Studi tentang Transformasi Kawasan”. Jurnal Muara Sains, Teknologi, Kedokteran, dan Ilmu Kesehatan vol 4 No. 2 Oktober 2020 hal. 295-310
} 
Masalah dimulai ketika pihak PAM Jaya menyatakan bahwa lahan yang berada di Jalan Leuser RT08/08, Kelurahan Gunung, Kebayoran Baru merupakan milik PAM Jaya dengan sertifikat HGB nomor 1621/Gunung atas nama Perusahaan Daerah Air Minum Daerah Khusus Ibu Kota Jakarta (PAM Jaya) yang terbit pada 24 Agustus 2012. Rencananya, PAM Jaya ingin mengambil alih lahan tersebut untuk diberikan kepada Pemda DKI dan dikembalikan fungsinya menjadi Ruang Terbuka Hijau (RTH). Warga yang tinggal di lahan tersebut (selanjutnya disebut Kampung Leuser) dengan tegas menolak rencana penggusuran yang hendak menimpa kampung mereka; mereka berargumentasi bahwa tanah ini adalah milik mereka dan mereka tidak akan membiarkan pihak mana pun yang mencoba merampasnya. Mereka mengklaim bahwa mereka sudah menempati lahan tersebut sejak tahun 1955. Bahkan mereka juga mengaku bahwa mereka sudah membayar pajak bumi dan bangunan sejak tahun 1967. Warga juga melakukan perlawanan dengan menggugat balik BPN (Badan Pertanahan Nasional) sebagai pihak yang mengeluarkan sertifikat HGB kepada PAM Jaya, dengan bantuan dari Lembaga Bantuan Hukum (LBH) PBHI dan LBH Tridharma.

Dengan menggunakan sengketa lahan tersebut sebagai 'jendela' (window) pengamatan, peneliti akan mengkaji tantangan dan prospek permukiman informal di Kebayoran Baru tersebut. Tantangan dirumuskan berdasarkan latar belakang, proses, dan perkembangan penguasaan lahan tersebut saat ini. Sementara, prospek disajikan sebagai skenario jalan keluar yang dapat ditempuh, skenario pesimis, moderat, maupun optimis.

\section{Rumusan Masalah}

Fokus telaah ini adalah mengkaji tantangan keberadaan permukiman informal Kampung Leuser di Kota Baru Kebayoran Baru. Dengan memahami tantangan tersebut, maka akan ditelaah pula prospek perkembangannya di masa yang akan datang.

\section{METODE PENELITIAN}

Penelitian ini menggunakan pendekatan penelitian kualitatif. Menurut Furchan (1992), penelitian kualitatif adalah salah satu prosedur penelitian yang menghasilkan data deskriptif tentang pikiran, perilaku, dan nilai-nilai orang atau masyarakat yang diamati. Melalui penelitian kualitatif, penulis dapat mengenali subjek dan berusaha memahami apa yang mereka alami dan rasakan dalam kehidupan sehari-hari. Penelitian kualitatif adalah penelitian yang dilaksanakan pada kondisi (setting) alamiah. Lebih spesifik lagi, penelitian ini juga menggunakan pendekatan semi autonomous social field, yang berkembang dalam bidang antropologi hukum. Menurut Sally Falk Moore (1973), pencetusnya, pendekatan semi autonomous social field mengandaikan adanya social field (misalnya komunitas) yang cukup besar dan otonom untuk mengembangkan aturan-pakai dan normanya sendiri, namun cukup kecil dan rentan untuk dipengaruhi oleh aturan-pakai dan keputusan yang dipaksakan oleh lingkungan yang mengelilinginya (1973: 720). Penelitian ini menempatkan Kampung Leuser dan warganya, beserta aturan-pakai (rules-in-use) yang berkembang di dalamnya sebagai social field yang semi-autonomous tersebut.

Hubungan Pemerintah DKI Jakarta dan warga Kampung Leuser tidak selalu harmonis; dalam kasus sengketa yang menjadi 'jendela' pengamatan ini, hubungan tersebut menegang. Penelitian ini akan menggunakan sengketa agraria tersebut sebagai jendela untuk memahami posisi masingmasing pihak. Diyakini, dalam situasi sengketa, masing-masing pihak akan menyampaikan argumentasi dan klaimnya yang terkuat (agar dapat memenangkan sengketa); dari klaim-klaim tersebut, tantangan dan prospek dapat dikonstruksikan. 
Dalam penelitian ini, peneliti memperoleh data penelitian dari dokumen-dokumen hukum (legal documents) yang diajukan oleh kedua pihak yang bersengketa di pengadilan. Data ini adalah data yang telah terdokumentasi dengan baik dan terdapat di pengadilan maupun kantor Lembaga Bantuan Hukum, sehingga keabsahan data dapat dipertanggungjawabkan. Selain itu, legal documents tersebut juga dapat dinilai merupakan salah satu sumber data/ informasi terlengkap dan, karenanya, juga merupakan sumber utama penelitian ini. Melengkapi dokumen hukum, penulis juga melakukan pengumpulan data primer (wawancara dengan warga, pihak terkait, dan observasi lapangan), serta pengumpulan data sekunder. Data-data yang telah dikumpulkan ini kemudian diolah sehingga peneliti dapat memperoleh informasi mendalam mengenai fokus kajian, serta struktur dan dinamika komunitas di Kampung Leuser

\section{HASIL DAN PEMBAHASAN}

\section{Kota Baru Kebayoran Baru}

Kebayoran Baru adalah kota baru yang dirancang untuk menjadi kota penyangga Jakarta dan secara administratif terpisah dari kota Jakarta. Kebayoran Baru direncanakan pada tahun 1948, tiga tahun setelah Belanda kembali menduduki Jakarta. Dalam rekonstruksi tersebut pemerintah Belanda membentuk komite rekonstruksi pusat (Centrale Stichting Wederopbouw, atau CSW). Komite ini diketuai oleh Mr. MAF Zwager, dan beranggotakan Ir. EWH Clason, praktijk ingenieur M Soesilo, dan H Masoud. Komite ini berhasil mendapatkan lahan $\pm 730 \mathrm{Ha}$ untuk dijadikan area pengembangan kota satelit ${ }^{2}$, dengan jarak sekitar 8 kilometer di Barat Daya dari pusat kota Jakarta (Sudiro 1953) ${ }^{3}$. Sampai sebelum penyerahan kedaulatan (27 Desember 1949), pengembang Kebayoran Baru telah menyelesaikan pembangunan lebih dari 2000 rumah, 42 km jaringan jalan, dan $17 \mathrm{~km}$ saluran air bersih (Kuswartojo 2019: 146).

Pada 1950, melalui UUD Sementara pasal 46, ibukota negara dinyatakan kembali ke Jakarta. Akibatnya, diperlukan tambahan tempat tinggal bagi pegawai negeri yang kembali ke ibukota. Oleh karena itu, pada akhir tahun 1950, mulai dibangun tambahan hunian sebanyak 1000 unit di Kebayoran Baru. Menurut Castles (2007), Kebayoran Baru diputuskan menjadi bagian dari Ibukota Jakarta pada tahun 1950. Hal ini didasari oleh Keputusan Pemerintah mengenai luas dan batas-batas wilayah Kotapradja Djakarta. Saat ini Kecamatan Kebayoran Baru memiliki luas $1.291 \mathrm{Ha}$, atau bertambah $561 \mathrm{Ha}$ dari luas awal kota baru Kebayoran Baru. Saat ini ada sepuluh Kelurahan di dalam Kecamatan Kebayoran Baru, yakni:

Tabel 1. Daftar Kelurahan di Kecamatan Kebayoran Baru Sumber: BPS dan olahan penulis

\begin{tabular}{cccc}
\hline No. & Kelurahan & Luas $($ Ha) & Persentase \\
\hline 1 & Gandaria Utara & 152 & 11.76 \\
\hline 2 & Cipete Utara & 183 & 14.16 \\
\hline 3 & Pulo & 127 & 9.83 \\
\hline 4 & Petogogan & 86 & 6.66 \\
\hline 5 & Melawai & 125 & 9.67 \\
\hline
\end{tabular}

\footnotetext{
${ }^{2}$ Kota satelit Kebayoran adalah istilah yang digunakan oleh perencana Kebayoran Baru, yakni M. Soesilo. Lihat Soesilo, nd:319

${ }^{3}$ Setelah pengakuan kedaulatan, nama CSW diubah menjadi "Jajasan Pemugaran Pusat". Selain itu, pengaturan keuangan (financieringsregeling) yang sebelumnya merupakan wewenang CSW kemudian di kesampingkan. Begitu pula dengan lembaga-lembaga lainnya yang sebelumnya berada di bawah CSW selanjutnya melepaskan diri dari ikatan tersebut dan menjadi lembaga mandiri, seperti misalnya Stichting Wederopbouw Oost Indonesia dan Plaatselijk Opbouwdiensten (POD) (Sudiro 1953).
} 


\begin{tabular}{|c|c|c|c|}
\hline 6 & Kramat Pela & 125 & 9.67 \\
\hline 7 & Gunung & 132 & 10.22 \\
\hline 8 & Selong & 140 & 10.84 \\
\hline 9 & Rawa Barat & 69 & 5.34 \\
\hline 10 & Senayan & 153 & 11.84 \\
\hline
\end{tabular}

\section{Profil Kampung Leuser}

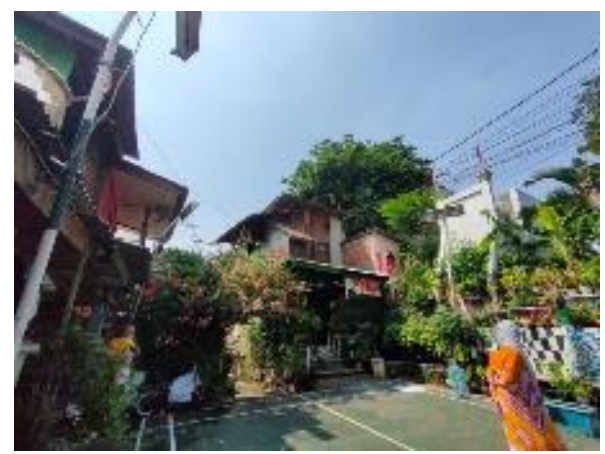

Gambar 2. Foto Kondisi Kampung Leuser Saat Ini

Sumber: dokumentasi penulis

Kampung Leuser merupakan sebuah kampung yang terletak di Jl. Leuser, tepatnya di RT005, 006, 007, 008, 010, RW 08, Kelurahan Gunung, Kecamatan Kebayoran Baru, Jakarta Selatan. Kampung Leuser memiliki luas kurang lebih 1,1 Hektar. Saat ini (2019) Kampung Leuser dihuni oleh sekitar $100 \mathrm{KK}$, dengan $80 \mathrm{KK}$ terdaftar dan tinggal di tempat, dan $20 \mathrm{KK}$ terdaftar dan tidak tinggal di tempat. Jumlah warga yang terdaftar dan tinggal di tempat adalah 309 jiwa, dengan 203 penduduk terdaftar dan 106 pengontrak terdaftar. Kampung Leuser sendiri merupakan permukiman padat penghuni dan menempati tanah milik PAM Jaya, yang berdasarkan rencana kota Kebayoran Baru tahun 1948 dan RTRW 2010 merupakan jalur hijau dengan fungsi awal sebagai RTH.

\section{Kampung Leuser Saat Ini: Tantangan terhadap Eksistensi}

Tantangan terpenting bagi eksistensi Kampung Leuser bermula pada 2016. Pada bulan April 2016, setelah warga tinggal di Kampung Leuser, menurut pengakuannya, selama kurang lebih 60 tahun, lahan tempat tinggal mereka digugat oleh PAM Jaya dengan melayangkan Surat Peringatan pertama (SP-1). Akibatnya, warga melakukan demo dan memblokir jalan masuk ke kampung mereka. Pada tahun 2016, warga dengan didampingi oleh PBHI dan LBH Tridharma, didukung oleh mahasiswa, menggugat BPN selaku pihak yang mengesahkan hak PAM Jaya atas lahan tersebut.

Menurut Ilham (wawancara, November 2019), aktivis LBH Tridharma yang mendampingi warga, PAM Jaya tidak menggunakan hak atas tanah itu sesuai dengan ketentuan yang ada pada Peraturan Pemerintah No. 40 th 1996 tentang Hak Guna Usaha, Hak Guna Bangunan dan hak Pakai atas Tanah. Pasal 26 (1) PP tersebut antara lain mengatur bahwa permohonan pemegang hak dapat diperpanjang jika tanah masih dipergunakan dengan baik sesuai tujuan pemberian hak tersebut. Sebaliknya, justru masyarakatlah yang menguasai dan memelihara tanah tersebut dengan itikad baik, salah satunya dengan membayar Pajak Bumi dan Bangunan (PBB). Saat ini, sengketa tersebut telah dimenangkan oleh BPN, baik di tingkat pengadilan negeri maupun banding, meskipun warga masih mengajukan Peninjauan Kembali (wawancara dengan Ilham, 
November 2019). Karena itu, saat ini Kampung Leuser cenderung menjadi tertutup bagi orang luar karena kekhawatiran jika ada aparatur pemerintah datang untuk mengeksekusi keputusan pengadilan tersebut.

\section{Sengketa lahan: warga Kampung Leuser vs PAM Jaya}

Menurut Prihatin (2014), penggusuran memiliki dua sisi yang berlawanan. Bagi pihak yang kontra, penggusuran menyebabkan rusaknya jaringan sosial dalam bertetangga dan berkeluarga, rusaknya kestabilan kehidupan keseharian seperti bekerja dan bersekolah, dan juga melenyapkan aset hunian. Sementara, bagi mereka yang pro, penggusuran harus dilakukan karena hasil dari penggusuran tersebut adalah terciptanya suasana kota yang layak huni dan nyaman. Penggusuran juga diyakini sebagai bentuk lain pelayanan kepada masyarakat kota dan penegakan hukum, dengan tujuan mengembalikan hak-hak warga kota yang selama ini terampas ruang publiknya.Selain itu, masih menurut pihak yang pro, dalam beberapa kasus penggusuran dilakukan dengan tujuan mengembalikan hak-hak pemilik lahan yang sah menurut hukum.

Mengikuti pandangan pro dan kontra di atas, maka kasus ini juga perlu dilihat dari dua sudut pandang, yakni menurut sudut pandang warga Kampung Leuser selaku pihak yang hendak digusur, dan menurut sudut pandang PAM Jaya sebagai pihak yang hendak menggusur, sehingga dapat diperoleh pandangan yang seimbang dan adil. Penulis akan menggunakan wawancara sebagai sumber data primer, dan argumen dari kedua belah pihak sebagaimana tersaji dalam dokumen hukum sebagai sumber data sekunder.

\section{Argumentasi kedua belah pihak}

a. Argumen pertama yang diketengahkan oleh pihak warga Kampung Leuser adalah kandungan pasal 24 PP 24 tahun 1997 tentang Pendaftaran Tanah. Pasal tersebut menyatakan bahwa warga dan pendahulu-pendahulunya yang sudah menghuni suatu bidang tanah selama 20 tahun atau lebih secara berturut-turut dan dengan itikad baik, dapat memiliki hak untuk mengajukan kepemilikan tanah. Menurut keterangannya, warga sudah menempati lahan tersebut sejak tahun 1955. Dengan demikian, warga merasa berhak untuk tetap tinggal di lahan tersebut.

Menanggapi argumen tersebut, pihak BPN mengatakan bahwa terkait dengan asal mula permukiman di Kampung Leuser, pihak PAM Jaya mengatakan bahwa awalnya di lahan tersebut terdapat mesin pompa, rumah pompa, dan rumah dinas untuk operator pompa. Tetapi setelah tidak digunakan lagi, ada 9 karyawan PAM Jaya yang meminta izin untuk tinggal di lahan tersebut, dan pihak PAM Jaya memberikan izin dengan syarat harus dijaga dengan baik dan penghunian bersifat sementara. Hal ini dibuktikan dengan surat yang dikeluarkan pada tahun 1960 oleh Ach. Djoenaedi selaku Kepala Bagian Saluran Air Minum P.C.K kepada Fatah selaku karyawan PAM Jaya.

b. Argumen kedua adalah mengenai pembayaran PBB yang sudah warga lakukan sejak tahun 1967. Pembayaran PBB sejak tahun 1967 menandakan warga sudah menjalankan kewajibannya sebagai pihak yang menguasai suatu bidang lahan dan/atau bangunan.

Menanggapi argumen tersebut, Dr. Nurhasa Ismail selaku saksi ahli dari pihak BPN mengatakan bahwa mengacu pada UU No. 12 tahun 1985 tentang Pajak Bumi dan Bangunan (PBB), kewajiban membayar PBB tidak harus dilakukan oleh pemilik. Kewajiban pajak itu bisa dibayarkan oleh siapa pun yang memanfaatkan dan/atau menggunakan tanah, bahkan orang yang secara tidak sah menguasai, menggunakan dan/atau memanfaatkan tanah, oleh 
kantor Pajak tetap akan dikenakan pajak. Jadi PBB tidak harus dilekatkan pada kepemilikan; siapa saja yang menggunakan atau memperoleh manfaat dari tanah harus membayar PBB. Dengan kata lain, pembayaran PBB tidak harus dimaknai sebagai pemilik karena dia bisa saja sebagai pemakai, bahkan pemakai yang tidak sah pun oleh Kantor Pajak tetap akan ditarik pajak.

c. Argumen ketiga, warga Kampung Leuser mengaku tidak pernah mendapat sosialisasi dari pihak Pemda ataupun PAM Jaya terkait dengan rencana penggusuran yang hendak dilakukan. Surat peringatan 1 diberikan secara tiba-tiba, tanpa adanya peringatan terlebih dahulu.

Menanggapi argumen tersebut, pihak BPN mengatakan bahwa pihak PAM Jaya sebenarnya sudah 3 kali mengundang warga untuk datang ke Kantor Kecamatan, namun warga tidak pernah hadir. Hal ini dibuktikan dengan surat undangan yang diberikan kepada warga.

\section{Kajian terhadap Argumentasi Para Pihak}

a. Berdasarkan argumen pertama dapat disimpulkan bahwa pada dasarnya pihak PAM Jaya lah yang mengeluarkan surat izin kepada 9 karyawan PAM Jaya untuk dapat menempati lahan di Jalan Leuser. Namun, seiring berjalannya waktu semakin banyak warga di luar karyawan PAM Jaya yang ikut membangun rumah di kawasan tersebut. Pihak PAM Jaya juga terus melakukan pembiaran selama berpuluh-puluh tahun. Akibatnya, permukiman terus bertambah padat dan warga merasa memiliki hak atas tanah yang mereka tempati.

b. Berdasarkan argumentasi kedua dapat disimpulkan bahwa secara hukum, bukti pembayaran PBB tidak dapat dijadikan bukti kepemilikan. Setiap orang yang memanfaatkan, menggunakan, dan menguasai lahan baik secara sah maupun tidak sah tetap memiliki kewajiban untuk membayar PBB. Namun, secara sosial, pembayaran PBB dapat dipandang sebagai semacam pengakuan bahwa penarik pajak mengakui pihak tertentu tersebut sebagai pihak yang menguasai lahan secara efektif.

c. Berdasarkan argumentasi ketiga, menurut keterangan Ilham (wawancara, 2019), warga memang dianjurkan oleh LBH pendamping untuk tidak menghadiri sosialisasi yang diadakan oleh Pemda. LBH mengatakan bahwa bila warga datang, maka kehadiran warga bisa disalahgunakan oleh pihak yang tidak bertanggung jawab. Contohnya, LBH mengkhawatirkan bila daftar hadir yang diberikan oleh Pemda ternyata dimanipulasi menjadi daftar warga yang menyatakan persetujuan untuk penggusuran. Selain itu, bila menghadiri sosialisasi maka bisa jadi pihak warga sudah dianggap menyetujui untuk dilakukan penggusuran.

\section{Prospek masa depan Kampung Leuser: Skenario Optimis, Moderat, dan Pesimis}

Dengan menggunakan kasus sengketa lahan di atas sebagai 'jendela' untuk memahami latar belakang, proses dan perkembangan penguasaan lahan tersebut hingga saat ini, maka dapat diperkirakan prospek masa depan Kampung Leuser tersebut, yakni berupa tiga skenario, yakni: skenario optimis, skenario pesimis, dan skenario moderat..

\section{Skenario optimis}

Skenario optimis, yakni eksistensi Kampung Leuser tetap berlanjut, dirumuskan dengan mengacu ke studi Fernandes (2011) dan Srinivas (1991). Menurut kedua penulis tersebut, setidaknya ada tiga karakteristik dari permukiman informal, yaitu:

a. Karakteristik Fisik 
Kriteria fisik dapat mencakup ada-tidaknya infrastruktur dan pelayanan publik yang memadai; memadai-tidaknya konstruksi bangunan; terjadi-tidaknya degradasi lingkungan; ada-tidaknya ruang publik untuk komunitas, dan fasilitas budaya; dan dominan-tidaknya penduduk miskin. Dalam beberapa survei, permukiman yang tidak memiliki satu atau dua kriteria ini sudah cukup untuk diklasifikasikan sebagai permukiman informal.

b. Karakteristik Sosio-ekonomi

Profil sosial ekonomi masyarakat yang tinggal di permukiman informal dapat menjadi kriteria untuk mendefinisikan informalitasnya. Kebanyakan orang yang tinggal di permukiman informal memang miskin, dan sebagian besar indikator sosial ekonomi, pendidikan, kesehatan, kematian, pendapatan, dan pekerjaan, menunjukkan pendapatan rendah dan kondisi hidup serta perumahan yang berkualitas buruk. Selain itu, permukiman informal sering kali dianggap sebagai sarang dari berbagai perilaku sosial yang menyimpang. Ditemukannya berbagai perilaku menyimpang yang bertentangan dengan norma sosial, tradisi, dan kelaziman yang berlaku sebagaimana kehendak sebagian besar masyarakat menjadi penyebab munculnya stigma negatif ini. Bentuk perilaku menyimpang dimaksud antara lain adalah mabuk-mabukan, menggunakan obat terlarang, pelacuran, adu ayam, dan perbuatan mengganggu ketertiban umum lainnya. Meski tidak dilakukan oleh semua warga permukiman informal, namun karena status sosial dan ekonomi yang rendah, maka banyak ditemukan para remaja dan pengangguran yang berlaku demikian. Akibat lebih lanjut dari perilaku menyimpang ini dapat mengarah kepada tindakan kejahatan seperti pencurian, pemerkosaan, penipuan, penodongan, pembunuhan, perusakan fasilitas umum, tawuran, melakukan pungutan liar, mencopet, dan tindakan kekerasan lainnya.

c. Aspek Legal

Penentu mendasar dan karakteristik hampir semua permukiman informal adalah pelanggaran terhadap sistem hukum yang ada. Permukiman informal sering kali memiliki karakteristik fisik yang serupa, tetapi masalah hukumnya yang berbeda dan spesifik memiliki implikasi yang beragam. Permukiman informal biasanya memiliki satu atau lebih bentuk intrinsik ketidaksahan (illegality), melalui pelanggaran kepemilikan tanah pribadi, publik, dan umum; peraturan dan standar perkotaan; lingkungan, atau bangunan; persyaratan pendaftaran; dan ketentuan perpajakan.

Dari ketiga karakteristik di atas, sebenarnya Kampung Leuser hanya memenuhi aspek legal saja untuk disebut sebagai permukiman informal.

a. Untuk karakteristik pertama, Kampung Leuser dapat dikatakan memiliki hampir seluruh karakteristik yang dimiliki permukiman formal. Pertama, hampir seluruh rumah di Kampung Leuser saat ini relatif permanen, sudah memiliki sistem sanitasinya sendiri. Jadi mulai dari jaringan air bersih, hingga pembuangan limbah sudah berjalan dengan baik. Kemudian, Kampung Leuser juga memiliki Ruang Sekretariat yang menjadi ruang serbaguna, baik untuk rapat, ataupun untuk perkumpulan pengurus kampung. Selanjutnya, Kampung Leuser juga sudah membangun rumah baca. Namun, untuk saat ini rumah baca belum beroperasi karena adanya sedikit masalah dari pihak donor (wawancara dengan Ganda, November 2019).

b. Untuk karakteristik kedua, profil pekerjaan penduduk Kampung Leuser adalah pekerja kantoran dan pedagang. Menurut Edi (wawancara, Desember 2019), sekitar 60\% warga di Kampung Leuser bekerja sebagai pedagang di Pasar Mayestik. Selain itu, ada juga sekitar $20 \%$ yang bekerja di instansi pemerintah seperti Pak Edi tersebut dan Pak Robi ketua RT 008, yang bekerja di PAM Jaya. Terakhir, ada sekitar $20 \%$ warga yang membuka warung makan di 
sekitar Kampung Leuser. Bahkan salah satu warung makan di sana, yakni Rumah Makan Pak Tardja, sudah menjadi warung makanan legendaris di Kebayoran Baru.

Selama menghadapi ancaman penggusuran tersebut, terbukti warga dapat mengorganisasikan diri dengan baik, dengan struktur kepemimpinan formal dan non-formal yang bekerja dengan baik. Kemudian, mengenai stigma negatif akibat perilaku menyimpang yang sering kali ditemukan di permukiman informal, data lapangan di Kampung Leuser tidak menunjukkan hal yang demikian. Berdasarkan pengamatan dan wawancara peneliti, Kampung Leuser adalah kampung yang bebas dari 'penyakit' masyarakat. Baik itu mabuk-mabukan, penggunaan narkoba, pelacuran, perjudian, dan perbuatan yang mengganggu ketertiban umum lainnya. Terakhir, kasus pelacuran yang diduga pernah terjadi di Kos Tengku, tidak lagi muncul setelah rumah kos tersebut terbakar pada tahun 2001. Berdasarkan pengakuan Titin (wawancara, Desember 2019), Kampung Leuser bahkan menjadi kampung yang paling aktif dalam kegiatan di Kelurahan maupun Kecamatan. Hal ini terbukti dari banyaknya piala yang terkumpul di ruang Sekretariat RT 008/08.

c. Untuk karakteristik ketiga, memang secara hukum sertifikat HGB dimiliki oleh PAM Jaya. Namun, ada beberapa hal yang tetap dapat mendukung warga Kampung Leuser. Salah satunya adalah PP 24 tahun 1997 tentang Pendaftaran Tanah yang menyatakan bahwa bila warga sudah menghuni selama 20 tahun berturut-turut dan dengan itikad baik, maka warga berhak mengajukan kepemilikan tanah.

Selain terbantahnya karakteristik permukiman informal, faktor yang dapat mendukung bertahannya Kampung Leuser adalah program pemerintah dalam menangani permukiman informal. Program penanganan permukiman informal sudah mulai dilakukan oleh pemerintah sejak tahun 1980. Selain itu, pemerintah Indonesia juga mempromosikan program sertifikasi tanah (PST) sebagai strategi nasional untuk memfasilitasi pembangunan nasional. Promosi ini telah dilakukan dengan melaksanakan program nasional seperti Proyek Operasi Nasional Agraria (PRONA) pada tahun 1981, dan Layanan Rakyat Untuk Sertifikasi Tanah (LARASITA) di tahun 2006, yang diluncurkan oleh Badan Pertanahan Nasional (BPN) untuk memfasilitasi PTS di daerah perkotaan dan pedesaan di Indonesia (Wahid, 2015).

Pemerintah saat ini juga memberikan perhatian yang besar terhadap masalah agraria. Sejak tahun 2014, pemerintah Indonesia semakin aktif mempromosikan PST di Indonesia. Hal ini dimulai dengan memperbaiki birokrasi yang mahal dan tidak efektif agar dapat mencapai misi pemerintah untuk menerbitkan 60 juta sertifikasi tanah pada tahun 2021. Presiden Joko Widodo juga berjanji bahwa pemerintah akan memberikan sertifikat tanah kepada masyarakat setiap hari, dan akan memantaunya dengan saksama (Adi, 2016). Keseriusan ini menunjukkan bahwa pemerintah Indonesia percaya bahwa PST dapat mendukung pembangunan Indonesia. Kiranya program pembagian sertifikat tersebut dapat juga dimanfaatkan oleh warga Kampung Leuser. Apabila warga Kampung Leuser berhasil menerima pembagian sertifikat, maka keberadaan Kampung Leuser akan terus berlangsung.

\section{Skenario pesimis}

Selain mengkaji skenario optimis, perlu juga memprediksi skenario terburuk yang mungkin terjadi terhadap warga Kampung Leuser. Skenario pesimis pertama yang mungkin terjadi adalah pengokohan hak PAM Jaya atas lahan tersebut. Bila hal ini berlanjut, maka semakin sulit bagi warga Kampung Leuser untuk tetap dapat bertahan di Kampung Leuser. 
Skenario terburuk selanjutnya yang mungkin menimpa warga Kampung Leuser adalah terjadinya penggusuran. Penggusuran terhadap warga Kampung Leuser merupakan hal yang sangat mungkin terjadi. Bahkan hingga saat ini, sudah dua kali gugatan warga ditolak, yakni oleh Pengadilan TUN Jakarta Selatan dan Mahkamah Agung. Demikian pula dengan bukti-bukti yang dimiliki oleh PAM Jaya, seluruhnya memberikan dukungan terhadap posisi PAM Jaya.

Belum berhenti di situ, jika penggusuran sampai menimpa warga Kampung Leuser, maka skenario terburuk selanjutnya adalah tidak adanya ganti rugi yang memenuhi harapan warga Kampung Leuser. Sebelumnya hal ini pernah menjadi isu pada tahun 1993. Saat itu warga juga terancam akan digusur karena pihak PAM Jaya berencana menggunakan lahan di Jalan Leuser. Pada saat itu, warga diwakilkan oleh Harun sebagai perwakilan eks karyawan PAM Jaya menyatakan keberatan karena, selain akan digusur, pihak PAM Jaya juga dianggap tidak memberikan ganti rugi yang sesuai. Bahkan PAM Jaya hanya akan memberikan uang kerohiman yang jumlahnya jauh di bawah harapan para warga. Selain itu, jika sampai penggusuran terjadi, akan ada banyak warga Kampung Leuser yang kehilangan mata pencaharian mereka.

\section{Skenario Moderat}

Selain skenario optimis dan pesimis, dapat juga dirumuskan skenario yang dapat menguntungkan kedua belah pihak. Untuk menanggapi permasalahan yang diajukan oleh Pemerintah kota terkait fungsi RTH yang ingin dikembalikan di lokasi penelitian, warga dibantu oleh PBHI dan LBH Tridharma, serta mahasiswa, telah mengembangkan konsep kampung hijau. Perwakilan dari LBH Tridharma, Ilham (wawancara Desember, 2019) mengatakan bahwa kawasan Jalan Leuser dapat dijadikan sebagai RTH tanpa harus melakukan penggusuran. Konsep kampung hijau tersebut antara lain berisi: pembersihan kali Jelawe, penanaman aneka tanaman hijau yang tidak hanya berfungsi untuk mempercantik kawasan, tetapi juga bisa dikonsumsi oleh warga (aneka sayur, bawang dan lainnya). Selain itu, kampung juga dibersihkan dan ditata sedemikian rupa sehingga layak untuk dikategorikan sebagai Kampung Hijau. Warga berharap, upaya tersebut dapat menjawab tujuan akhir Pemerintah kota, yaitu mengembalikan fungsi RTH pada lahan tersebut.

Selain aspek fisik, konsep kampung hijau juga menjangkau aspek ekonomi. Artinya, program kampung hijau yang diterapkan di Kampung Leuser juga memberikan keuntungan ekonomi bagi warganya, seperti menjadikannya sebagai kampung wisata. Sebagai contoh, program Kampung Hijau yang dipraktikkan di Kampung Jodipan, Malang, menunjukkan suksesnya program kampung hijau. Pada mulanya, Kampung Jodipan merupakan permukiman kumuh yang sudah beberapa kali hendak digusur oleh Pemerintah Kota Malang. Tetapi, dengan kerjasama warga dan bantuan mahasiswa, maka Kampung Jodipan diubah menjadi sebuah permukiman yang bersih dan bahkan menjadi tempat wisata. Jika Kampung Leuser dapat ditetapkan menjadi kampung wisata, maka bukan hanya warga yang diuntungkan, tetapi juga Pemerintah kota Jakarta Selatan.

\section{KESIMPULAN DAN SARAN}

\section{Kesimpulan}

\section{Tantangan terhadap eksistensi Kampung Leuser}

Sengketa lahan yang terjadi di Kampung Leuser dipicu oleh rencana pengambil-alihan lahan Kampung Leuser oleh PAM Jaya, dan menggusur warga penghuninya. PAM Jaya mengklaim memiliki hak atas tanah tersebut karena memiliki sertifikat HGB. Sedangkan warga Kampung Leuser merasa memiliki hak atas tanah tersebut karena sudah menempatinya sejak tahun 1955 dan taat membayar PBB sejak 1967 hingga sekarang. Dari argumentasi masing-masing pihak, 
dapat disimpulkan bahwa kedua pihak merupakan pelaku, sekaligus juga korban. Pihak PAM Jaya selaku pemegang sertifikat HGB atas tanah menjadi pelaku karena hendak menggusur warga yang sudah tinggal di atas tanah tersebut sejak tahun 1955. Warga yang notabene adalah warga miskin tidak seharusnya dikorbankan haknya atas tempat tinggal. Namun, PAM Jaya juga dapat dikategorikan sebagai korban karena sebagai pemegang sertifikat HGB atas tanah tersebut, justru tidak dapat mengelola tanah dan terancam kehilangan haknya.

Di lain pihak, warga Kampung Leuser dapat dikategorikan sebagai korban karena hak mereka untuk memiliki tempat tinggal hendak dirampas. Warga yang sudah tinggal di lokasi selama kurang lebih 60 tahun, hendak digusur karena tidak memiliki hak penguasaan atas tanah tersebut. Padahal, warga sudah pernah mengajukan permohonan untuk pembelian tanah, warga juga pernah mengajukan permohonan pengajuan sertifikasi tanah. Tetapi, semua usaha itu belum membuahkan hasil. Di sisi lain, warga Kampung Leuser juga bisa dikategorikan sebagai pelaku karena menguasai lahan yang bukan haknya.

Penelitian ini tidak memberikan moral judgment terhadap kebenaran salah satu pihak; yang dilakukan di sini adalah mengetengahkan sudut pandang dan argumentasi para pihak, untuk menjadi pertimbangan pengambil keputusan dan pihak-pihak lainnya. Kasus ini tidaklah unik, bahkan merupakan puncak gunung es, karena persoalan permukiman informal masih menjadi persoalan yang kerap mencuat menjadi konflik terbuka di berbagai kota di Indonesia.

\section{Prospek eksistensi Kampung Leuser}

Prospek Kampung Leuser ke depan dapat menggunakan skenario optimis, skenario pesimis, atau skenario moderat. Skenario moderat adalah skenario yang memberikan win-win solution.

Argumentasi pokok skenario optimis adalah terbantahnya dua karakteristik permukiman informal, yaitu karakteristik fisik, dan karakteristik sosio ekonomi. Untuk karakteristik fisik, Kampung Leuser sudah memiliki berbagai komponen yang tidak dimiliki permukiman informal. Sementara, untuk karekteristik sosio-ekonomi, profil pekerja di Kampung Leuser adalah pekerja kantoran (20\%), pedagang (60\%) dan pemilik usaha (20\%), seperti warung makan, di sekitar Kampung Leuser. Kemampuan warga untuk mengorganisasikan diri, baik secara formal maupun non-formal, terbukti baik. Stigma negatif akibat perilaku menyimpang yang seringkali ditemukan di permukiman informal tidak berlaku di Kampung Leuser. Berdasarkan pengamatan dan wawancara dengan warga, Kampung Leuser adalah kampung yang bebas dari 'penyakit masyarakat', baik mabuk-mabukan, penggunaan narkoba, pelacuran, perjudian, dan perbuatan yang mengganggu ketertiban umum lainnya.

Alasan utama yang mendasari skenario pesimis adalah bukti legal, berupa sertifikat HGB, yang dimiliki oleh PAM Jaya. Hal ini menjadi dasar dari pengambil-alihan yang hendak dilakukan. Berikutnya, adalah adanya rencana Pemerintah untuk mengembalikan fungsi lahan menjadi RTH. Tidak dapat dipungkiri, fungsi RTH adalah fungsi yang sangat diperlukan oleh warga Jakarta.

Skenario moderat adalah skenario menjadikan Kampung Leuser sesuai tujuan pengambil-alihan lahan yang dicanangkan oleh PAM Jaya, yakni mengembalikaan fungsi lahan tersebut sebagai RTH. Menurut argumentasi yang mendukung skenario ini, program kampung hijau sudah dilaksanakan di Kampung Leuser oleh para warga. Warga telah menata kampungnya, melakukan penghijauan, dan membangun fasilitas lingkungan yang diperlukan oleh warga kampung. Melalui program ini, terlihat bahwa penghijauan tetap dapat dilakukan tanpa harus melakukan 
penggusuran. Selain itu, melalui program ini, Kampung Leuser juga bisa dijadikan kampung wisata seperti halnya Kampung Jodipan di Malang.

\section{Saran}

Pertama, permukiman informal muncul akibat adanya pembiaran yang dilakukan oleh pihak pemagang hak. Apabila terjadi pembiaran, maka dalam sekejap waktu permukiman akan bertambah padat. Apabila sudah bertambah padat, maka masalah akan bertambah rumit. Maka dari itu lebih baik mencegah dari pada mengobati.

Berikutnya, faktor utama dari munculnya permukiman informal adalah kemiskinan. Masyarakat yang hidup dalam kemiskinan tentu tidak memiliki kemampuan untuk menyewa atau membeli rumah di permukiman formal; mereka akan mencari berbagai cara untuk dapat bertahan hidup, salah satunya adalah dengan menempati lahan yang tersedia, baik secara sah maupun tidak.

Terakhir, terkait dengan kasus yang terjadi di Kampung Leuser, maka pemerintah seharusnya bisa mencari jalan tengah yang menguntungkan kedua belah pihak. Bagaimanapun penggusuran merupakan pelanggaran terhadap hak hidup warga. Eksperimen Kampung Hijau yang telah diterapkan di berbagai kota seyogianya dapat diterapkan di Kampung Leuser, untuk keuntungan semua pihak.

\section{REFERENSI}

Adi, G.N. (2016). Jokowi Warns of Illegal Levies in Land Certification.

Castles, L. (2007). Profil Etnik Jakarta. Jakarta, Masup Jakarta.

Claudio, G. dan Fahmi, E. (2020). "Rencana Sabuk Hijau Timur Kota Baru Kebayoran: Kebijakan Setengah Hati? Studi tentang Transformasi Kawasan”. Jurnal Muara Sains, Teknologi, Kedokteran, dan Ilmu Kesehatan vol 4 No. 2 Oktober 2020

Fernandes, E. (2011). Regularization of Informal Settlements in Latin America. Boston, The Lincoln Institute of Land Policy.

Furchan, A. (1992). Pengantar Metode Penelitian Kualitatif. Surabaya: Usaha Nasional.

Kuswartojo, Tjuk. 2019. Kaca Benggala: Perkembangan Habitat Manusia Di Indonesia. Bandung: Ukara Lawang Buwana.

Moore, S. F. (1973). "Law and Social Change: The Semi-Autonomous Social Field as an Appropriate Subject of Study." Law \& Society Review 7(4): 719-746.

Prihatin, R. B. (2014). "Fenomena Penggusuran di Jakarta. Kajian Singkat terhadap Isu-Isu Terkini". Info Singkat Vol. VI No. 17/I/P3DI/September/2014. Jakarta.

Soesilo, Moh. nd. Perjalanan Hidup. tanpa nama penerbit

Srinivas, H. (1991). "Viability of informal credit to finance low-income housing: Case study of three squatter settlements in Bangalore, India". Unpublished master thesis. Bangkok, Asian Institute of Technology Division of Human Settlements Development.

Srinivas, H. (2005). "Defining Squatters Settlements." Global Development Research Center Web site 9.

Sudiro, M. (1953). Pembangunan Kotabaru Kebajoran. Jakarta, Kementerian Pekerdjaan Umum dan Tenaga R.I. Bagian Umum.

Wahid, F., Sæbø, Ø., \& Furuholt, B. (2015, May). "The Use of Information System in Indonesia's Land Management". Proceedings of the 13th International Conference on Social Implications of Computers in Developing Countries. Negombo, Sri Lanka. 